\title{
Use of Six Sigma and Kaizen Methods to Reduce Concrete Iron Defects (Case Study of PT. Hanil Jaya Steel)
}

\author{
Yustina Ngatilah ${ }^{1}$, Farida P. ${ }^{2}$, Alif L. ${ }^{3}$ \\ Department of Industrial Engineering \\ Universitas Pembangunan Nasional "Veteran" Jawa Timur \\ Surabaya, Indonesia \\ 1yustinangatilah@gmail.com
}

\author{
C. Pujiastuti ${ }^{4}$ \\ Department of Chemical Engineering, \\ Universitas Pembangunan Nasional "Veteran" Jawa Timur \\ Surabaya, Indonesia
}

\author{
Indri P. ${ }^{5}$ \\ Institut Sains and Teknologi Akprind Yogyakarta \\ Yogyakarta, Indonesia
}

\begin{abstract}
Concrete iron produced by PT. Hanil Jaya Steel still has product defects in the form of line defects, village defects, nguping defects and flattened tip defects of $3.22 \%$. The company wants to control the quality of this concrete iron, thereby reducing product defects. This study aims to determine the level of quality of concrete iron and provide suggestions for improvement to reduce disability. The results of this study are the level of product quality during the month of July-December 2017 at the level of sigma 3.9202 with DPMO of 8059.83. In JulyDecember there were several types of concrete iron product defects, namely line defects of $61.873 \%$, kampong defects of $\mathbf{2 0 . 3 3 6 5 \%}$, flattened tip flaws of $10.707 \%$, and earning defects of $\mathbf{7 . 0 5 5 \%}$. Factors that cause product defects are Human, Machine, Environment. Proposed improvements with the Kaizen method that can be used as a basis for quality improvement efforts, namely at the Seiketsu (maintenance) and Shitsuke (habituation) stages.
\end{abstract}

Keywords: Six Sigma; DMAIC; Kaizen.

\section{INTRODUCTION.}

At present, business people in the industry in Indonesia are aware of the ever changing customer orientation towards quality. In the increasingly tight industry competition, companies must be able to survive and compete with similar companies. In competition in the global market only good quality products will always be in demand, because quality is the fulfillment of services to consumers. Quality is the totality of the characteristics of a product that supports its ability to satisfy the specified or specified customer needs. Therefore the role of quality is needed in a company.

PT. Hanil Jaya Steel is a company located in Waru subdistrict, Sidoarjo, East Java. The company is engaged in manufacturing that produces concrete iron. In producing concrete iron, there are still defects in the production process. The defects that occur in concrete iron are nguping defects, scratch defects, village defects, flattened tip flaws.
From July to December 2017, there was a defect of deform 19 concrete iron products of $3.22 \%$. From the defects that occur in concrete iron, the company needs to do quality control. With this quality control, the company can reduce the product defect rate. One method of quality control to minimize the percentage of disability is six sigma.

The Six Sigma approach looks at the final product, assesses defects in products and looks for ways to eliminate the causes behind defects. This strategy aims to change the business process, if necessary, to produce the end product without flaw or make changes in the way the product is produced. Six Sigma is a process of measurement, seeing how the results deviate fromperfection and how to bring results closer to perfection[1]. Six sigma is deliberate, structure, effective way to develop solutions for sustained improvement[2]. Explores practicals solutons for contruction performance improvement by applying th six sigma principles.The principles provides the metric required to establish performance improvement goals and a methodology for measuring and evaluating improvement.The purposed approach is expected to achieve more realible workflows by reducing process variability to fit a desirable range- thereby improving the overall performance through the evaluationof the quality level in current construction operations [3].

The Kaizen approach looks at businesses with a wider lens. The aim is to improve every aspect of the business, create a standard process, improve efficiency and always look for ways to reduce waste. This is a system that always focuses on ways to improve, from beginner to highest level management [1].Kaizen event are a very effective, proven way to make rapid improvement[2].Kaizen is a Japanese philosophy and quality management method which involves continuous improvement through small incremental steps over a long period of time. Kaizen philosophy encourages an 'instinct for improvement' throughout the organisation. Improvement is 
seen as a 'way of life', not just the application of specific tools and techniques. Senior management commitment is vital for implementing Kaizen across an organisation.Kaizen can be used in the development of TQM [4].

The paper describes a theoretical approach of combining the continuous improvement philosophy of Kaizen with student course evaluation. Furthermore,the author uses evaluation data from two course cycles to describe results from a pilot application.A concept is illustrated for evaluating every single course unit and continuouslydiscussing these results together with the learners. Learners in the pilot courses accepted and welcomed the intense participation and allowed improvements mainly referring to course concept,content (and detail) selection, course material and presentation style. The participationrate declined during the term and was highly influenced by triggers like exam and grade relevance.[5]

As a result of the empirical work the authors proposed a new specific and individualizedframework for the public sector called: "Kaizen projects conceptual schemes (KPCS), based on thecycle Plan-Do-Check-Act in order to form a theoretical and practical guide that can serve as a base forlocal governments seeking to implement Kaizen in their management.[9]

The welding process in pipeline construction takes around $65 \%$ in the pipeline replacement project schedule and critical path for the project. From two previous segment, contractor have a reject welding ratio $14 \%$ and reject material $7 \%$, so it will be reduce into less than $5 \%$ and $3 \%$. The improvement process start from IPO diagram then the problem analyzed using fish bone. The improvement covered manpower skill, manpower certification, and procedure, and then resulted less rework and faster project. These improvements align with BSC Frame; Learning and innovation, Internal Process, Customer, and Financial.

[10]

Pere Grima, et al. Have grouped some of the most frequently into four main areas: implementation and organizational aspects, compliance with the DMAIC methodology, statistical tools and techniques and implementation of project improvements and closures (Six Sigma: practice to overcome difficulties (Six Sigma : instructions from exercises to overcome difficulties,Pere Grima, Lluís Marco-Almagro, Sandrine Santiago \& Xavier Tort-Martorell [11].Result shown that lean six sigma and continuous improvement (Kaizen) have positive influence for solving the problem of defect product [9].

Research results on Case Study: Reducing Sampling Time The following case studies illustrate the importance of combining Six Sigma with Kaizen activities. In four-wheel vehicle manufacturers, Black Belts complete Six Sigma projects during the sampling cycle of fully built (CBU) sampling units from cars. The cycle time for sample checking at the beginning of the project is around 24 hours, or three working days. At the end of the project, during the Control phase, time decreases dramatically to around 7.7 hours or one working day, thus reducing two-thirds of the cycle time. (Kaizen with Six Sigma Ensures Continuous Improvement
(Kaizen with Six Sigma Ensures Continuous Improvement) [10].

The paper reviews alarge number of papers in this field and presents the overview of varous continuous improvement practices demonstrated by manufacturing organizations globally [11].

The study in automotive industry Razmah Mahmoda, with lean six sigma and Kaizen contributes to the advancement of knowledge on methods to reduce defect products.Lean Six Sigma is widely used in many areas such as government, industry, healthcare andeducation. Big Data which is being collected in ever-increasing amounts due to digital commerce [12].

The study shows the importance of Six Sigma and Lean applications in three of the most important areas in oil and gas: Service quality drilling operations, customer satisfaction, and supply chain. Two successful case study projects are provided with step by step details and are organized around three main parts: the problem, the methodology and the lessons learned. Despite some misconception that some managers have about the implementation of Lean, it will stay the most efficient methodology to apply in the oil and gas business. Success of Lean depends also on top management decisions.[13]

This paper explores how Lean Six Sigma can beapplied to accelerate the process of extracting key insights from Big Data and also how Big Datacan bring new light and innovation to projects requiring the use of Lean Six Sigma. A casestudy approach using examples from both manufacturing and the service sector will be used inthis research.The results have shown that $55 \%$ ofemployees believe that the philosophy of kaizen is relatively applied in theelectricity sector. But there is a ratio of $65 \%$ of them think that theadministration of the total quality management is the most suitable to beapplied in the electricity and water sectors. In addition to that there is a ratioof about $50 \%$ see that both methods have achieved better improvements ofmaintenance in comparison with traditional methods, consequently bothmethods were successful in the electricity sector for improving maintenanceand reducing the cost.[14]

This paper presents a methodology for applying the Lean Six Sigma method on the educationalprocess. After defining defects that have negative influence on the final quality evaluation of highereducation and how these defects can be remedied, the Pareto analysis is done, and that is used forestablishing a vital minority of the exams that are critical for examination of faculty. The next stepis the Statistical Process Control (SPC) analysis that is performed on the exams that are classified asvital minority in Pareto analysis. Ishikawa diagram shows a relation between consideredconsequence (small number of passed exams) and all factors that influence this consequence. Basedon the results of implementation of the Lean Six Sigma method in the educational process andimplementation of all suggested improvements, the comparative overview of Pareto analysis is givenfor 2009/2010 and 2012/2013 academic year at the Faculty of Mechanical Engineering, University of Niš [15].

Determination of process capabilities for attribute data: 
Attribute data is qualitative data that is calculated using a split or tally list for recording and analysis purposes. Attribute data is discrete. If a record is only a summary or classification related to a set of requirements. Examples of quality characteristic attributes are: the absence of labels on product packaging, errors in the administration process of customer savings books, the number of types of defects in products, the number of plywood products that are defective due to colorings, etc.

Defect or disability is a disability to provide what the customer wants. While the defect per opportunity (DPO) is a measure of failure calculated in the six sigma quality improvement program, which shows the number of defects or failures per one opportunity, calculated using the DPO formula. Where the DPO formula is the number of defects or failures found are divided by (the number of units examined multiplied by the number of potential CTQs that cause defects or failure). DPMO is a measure of failure in a six sigma quality improvement program, which shows a failure of opportunity opportunities, to calculate using a formula:

$\mathrm{DPMO}=\mathrm{DPO} \times 1,000,000$

DMAIC (define, measure, analyze, improve, control)

DMAIC is a process for continuous improvement towards the Six Sigma target. DMAIC is carried out systematically, based on knowledge and facts. This process eliminates nonproductive process steps, often focuses on new measurements, and sets technologies to improve quality towards the Six Sigma target.

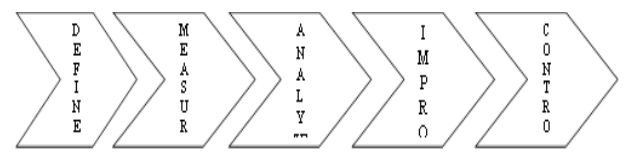

Fig. 1. DMAIC process (Source: Gaspersz, 2011)

1. Define is the first operational step in the six sigma quality improvement program. At this stage, the most important thing to do is identify the product or process that will be repaired. We must set top priorities about which problems and / or opportunities for quality improvement will be handled first. The best project selection is based on identifying projects that are in line with the current needs, capabilities and organizational goals.

2. Measure is the second operational step in the six sigma quality improvement program. Especially for attribute data can be done using pareto diagrams to find out what potential CTQ is the biggest or highest causing failure.

3. Analyze is the third operational step in the six sigma quality improvement program. At this stage that needs to be considered are several things, namely: determining the capabilities / capabilities of the process, and identifying sources and root causes of disability or failure.

4. Improve is the fourth operational step in the Six Sigma quality improvement program. This step is carried out after the sources and root causes of quality problems are identified.

5. Control (control) is the last operational phase in six sigma quality improvement projects. At this stage the results of quality improvement are documented and disseminated, best practices that are successful in improving the standardized process and used as standard work guidelines, as well as ownership or in charge of the process, which means six sigma ends at this stage [16].

Kaizen is the Japanese terms KAI and ZEN literally mean "to change" and " for the better", and it has come to symbolize continuous improvement.[17].Kaizen can be defined on several levels :

- Aphilosophy of on-going, incremental continuous improvement

- The process of making small incremental improvements on a daily basis

- An attitude within the workforce, that they have the responsibility to identify and participate in potencial improvements

- A mind -set that as always striving for perfection [2].

Practicals Implications the paper is intended to be equally usefi

Ul to both academics and practitioners who are interest on the topic of lean six sigma(LSS).From a pure practical standpoint, the paper provides an overview of the past, present and future trends of LSS as a powerful business strategy and problem solving methodology for all industrial sectors, irrespective of their size and nature.[18]

The implementation of kaizen was carried out using four tools consisting of Kaizen Five Step Plan and Five M Checklist.

1. This Kaizen Five Step Plan (a 5-step plan) is an approach to the implementation of kaizen used by Japanese companies. This step is often called the 5-S movement which is a Japanese initials starting with the letter S. 5-S is a method of structuring and maintaining an intensive work area originating from Japan that is used by management in an effort to maintain order, efficiency, and discipline in work location while improving the overall performance of the company. The advantage of implementing the 5-S is to improve quality and safety / work safety. This can happen because of: reducing time and material waste, increasing production efficiency and productivity, increasing workers' morale and simplifying the work environment.

2. Five M Checklist focuses on the five keys that are seen in each process, namely: Man (operator or person), Machine (machine), Material (material or raw material), Meethods (method), Milieu (environment). Through data collection or brainstorming, it can be assessed how and how much each of the $\mathrm{M}$ factors contributes to problem solving or finding solutions. 


\section{RESULTS AND DISCUSSION}

TABLE I. DEFECTTYPESOF DEFORM CONCRETE IRON PRODUCTS 19 JULY - DECEMBER 2017

\begin{tabular}{|c|c|c|c|c|c|}
\hline Month & $\begin{array}{c}\text { Nguping } \\
(\boldsymbol{p c s})\end{array}$ & $\begin{array}{c}\text { Garis } \\
(\boldsymbol{p c s})\end{array}$ & $\begin{array}{c}\text { Kampong } \\
(\boldsymbol{p c s})\end{array}$ & $\begin{array}{c}\text { Ujung } \\
\text { Gepeng } \\
(\boldsymbol{p c s})\end{array}$ & $\begin{array}{c}\text { Total } \\
\text { Defect } \\
(\boldsymbol{p c s})\end{array}$ \\
\hline July & 103 & 1097 & 425 & 160 & 1785 \\
\hline August & 423 & 2452 & 300 & 65 & 3240 \\
\hline September & 50 & 316 & 120 & 294 & 780 \\
\hline October & 0 & 720 & 535 & 0 & 1255 \\
\hline November & 0 & 0 & 39 & 361 & 400 \\
\hline December & 50 & 905 & 388 & 70 & 1413 \\
\hline Total & 626 & 5490 & 1807 & 950 & 8873 \\
\hline
\end{tabular}

\section{Define Stage}

The define phase is the first operational step in the Six Sigma quality improvement program. At this stage, the most important is the identification of the product and / or process to be repaired. The problem that is often faced by this company is the high number of defects that occur in concrete iron products, especially deform type 19 . Determination of the research object is focused on the process of making deform type concrete iron products 19 because of the frequent defects. Based on table 1 can be seen the description of the histogram defect that occurs in the type of deform 19 concrete iron products in July - December 2017 can be seen in the picture as follows:

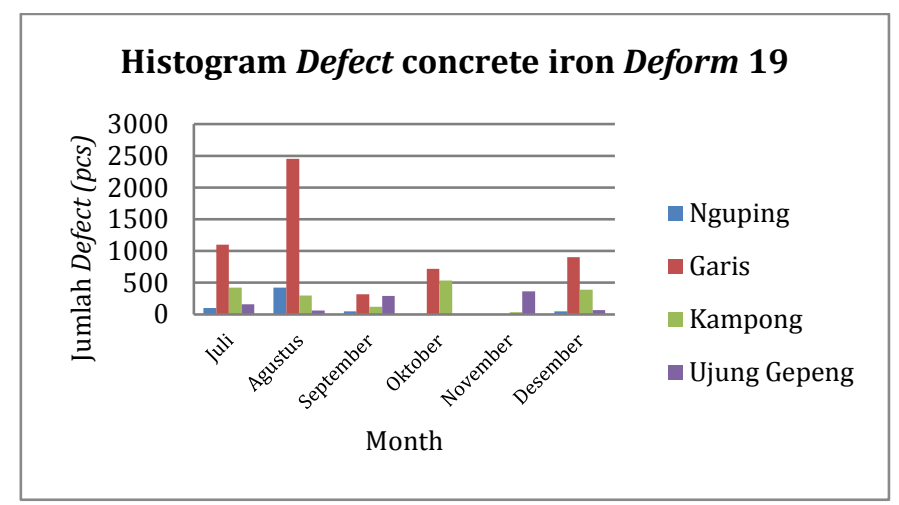

Fig. 2. Histogram Total Types Defect Concrete Iron Deform 19

Phase Measure

Measure is the second operational step in the six sigma quality improvement program. There are 3 main things that must be done in the measure phase, namely:

a. Determine the quality characteristics (CTQ) including eavesdropping, scratch defects, village defects and flattened tip defects

b. Determine the biggest defect

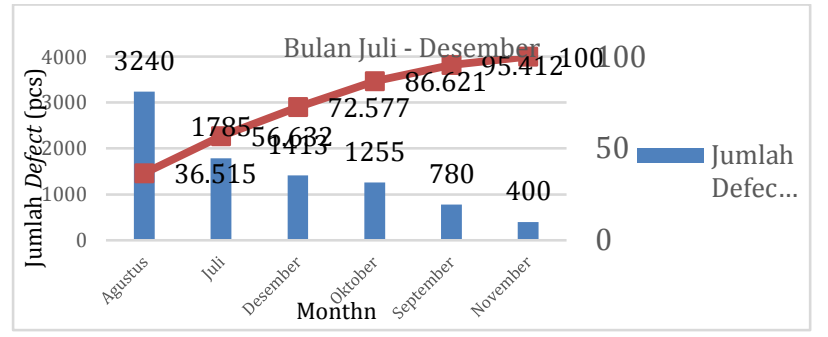

Fig. 3. Diagram Pareto Defect on July - December 2017

Based on Figure 3 can be seen the largest number of defects occurred in August, which amounted to 3240 pcs with a defect percentage of $36.515 \%$. Based on Figure 5 can be seen the largest type of defect that occurs is a line with the amount of 5490 pcs and the percentage of defects of $61.873 \%$

Phase Analyze

At this stage, identification of the sources of the root causes of defects in the concrete iron production process was carried out. The following is a fishbone diagram showing the root causes of defects in eavesdropping defects as follows:

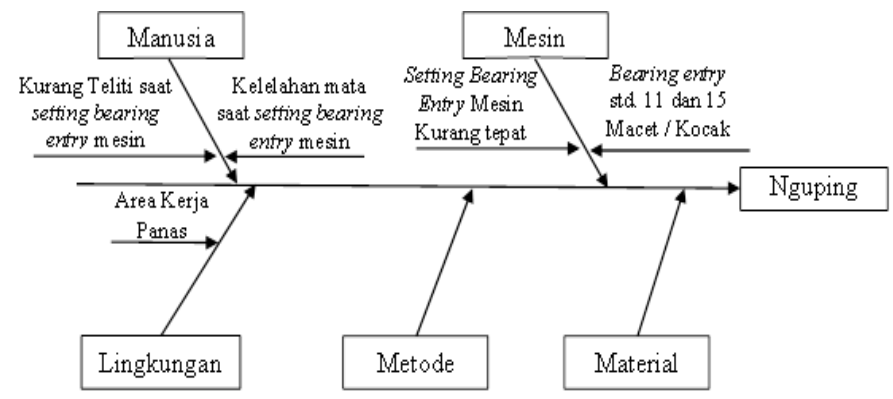

Fig. 4. Causal diagram

Improve phase

After the sources of the problems have been identified, the next step is to establish an improvement plan (action plan) to reduce the number of defects, the determination of corrective action plans aimed at improving quality. The improvement plan is obtained by means of brainstorming with the company. The implementation of this stage is only a proposal to the company. Where the proposed improvements made can provide input so that the number of defects can be reduced. The improvement is by implementing kaizen using the kaizen $\mathrm{M}$ checklist method and kaizen five step plan. 
a. Analysis Problem withkaizen five M checklist

TABLE II. ANALYSIS OF DISABILITY ISSUES NGUPING WITH KAIZEN FIVE M CHECKLIST

\begin{tabular}{|c|c|c|c|}
\hline No & Factor & Problem & $\begin{array}{c}\text { Problem Solving } \\
\text { (Proposed Improvement) }\end{array}$ \\
\hline 1. & Man & $\begin{array}{l}\text { 1. Eye fatigue when } \\
\text { setting engine } \\
\text { bearing entry } \\
\text { 2. Less careful when } \\
\text { setting the engine } \\
\text { bearing entry }\end{array}$ & $\begin{array}{l}\text { 1.Providing allowances to } \\
\text { workers } \\
\text { 2. Providing training for } \\
\text { refreshing SOP. } \\
\text { 3. The Head of Production } \\
\text { provides more strict } \\
\text { direction \& supervision } \\
\text { of workers. }\end{array}$ \\
\hline 2. & Machine & $\begin{array}{l}\text { 1. Setting the bearing } \\
\text { entry machine is less } \\
\text { precise } \\
\text { 2. Bearing entry STD. } \\
11 \text { and } 15 \text { are } \\
\text { jammed / funny }\end{array}$ & $\begin{array}{l}\text { 1. Paste / put manual } \\
\text { procedures for using the } \\
\text { machine around the } \\
\text { machine. } \\
\text { 2. Replace the Std Bearing } \\
\text { Entry. } 11 \text { and } 15 \text { with } \\
\text { good. }\end{array}$ \\
\hline 3. & Mileu & Hot work area & $\begin{array}{l}\text { Add blower and turbine } \\
\text { Roof Ventilator to the } \\
\text { production area }\end{array}$ \\
\hline 4. & Method & No cause occurred & - \\
\hline 5. & Material & No cause occurred & - \\
\hline
\end{tabular}

b. Improvement with Kaizen Five Step Plan

TABLE III. PROPOSED IMPROVEMENT WITHKAIZEN FIVE STEP PLAN

\begin{tabular}{|c|c|c|c|c|c|}
\hline \multirow[b]{2}{*}{ Problem } & \multicolumn{5}{|c|}{ Kaizen Five Step Plan } \\
\hline & Seiri & Seiton & Seiso & Seiketsu & Shitsuke \\
\hline $\begin{array}{l}\text { Man : } \\
1 \text {. Eye } \\
\text { fatigue when } \\
\text { setting } \\
\text { engine } \\
\text { bearing } \\
\text { entry } \\
\text { 2. Less } \\
\text { careful when } \\
\text { setting the } \\
\text { engine } \\
\text { bearing } \\
\text { entry }\end{array}$ & & & & $\begin{array}{l}\begin{array}{l}\text { Providing } \\
\text { allowances to } \\
\text { workers }\end{array} \\
\text { Providing } \\
\text { training for } \\
\text { refreshing } \\
\text { Standard } \\
\text { Operating } \\
\text { Procedure } \\
\text { (SOP) }\end{array}$ & $\begin{array}{l}\text { Get used to } \\
\text { working } \\
\text { accordingnglySt } \\
\text { andard } \\
\text { Operating } \\
\text { Procedure } \\
\text { (SOP) } \\
\text { Application of } \\
\text { strict } \\
\text { punishment } \\
\text { when making } \\
\text { mistakes } \\
\text { repeatedly. }\end{array}$ \\
\hline $\begin{array}{l}\text { Mechine: } \\
\text { 1. Setting } \\
\text { the bearing } \\
\text { entry } \\
\text { machine is } \\
\text { less precise } \\
\text { 2. Bearing } \\
\text { Entry std. } 11 \\
\text { dan } 15 \text { are } \\
\text { jammed / } \\
\text { funny } \\
3 . \text { RollG } \\
\text { uide std. } \\
13 \text { wear } \\
\text { out } \\
4 . \quad \text { Entry } \\
\text { std. } 13 \\
\text { dies } \\
\text { 5. std. } \\
14 \text { loop } \\
\text { position } \\
6 . \text { Leaky } \\
\text { oil hose } \\
7 . \text { RollGuid } \\
e \text { std. } 15 \text { aus }\end{array}$ & $\begin{array}{l}\text { Making } \\
\text { machine } \\
\text { grouping } \\
\text { data in } \\
\text { accordance } \\
\text { with the type } \\
\text { and function } \\
\text { in order to } \\
\text { change the } \\
\text { machine } \\
\text { Launching } \\
\text { machine } \\
\text { parts that are } \\
\text { vulnerable to } \\
\text { damage }\end{array}$ & $\begin{array}{l}\text { Place the } \\
\text { manual } \\
\text { for } \\
\text { machine } \\
\text { use } \\
\text { procedure } \\
\text { around } \\
\text { the } \\
\text { engine } \\
\text { area }\end{array}$ & $\begin{array}{l}\text { Leaning the } \\
\text { machine } \\
\text { after the } \\
\text { production } \\
\text { process }\end{array}$ & $\begin{array}{l}\text { Perform } \\
\text { regular } \\
\text { maintenance } \\
\text { of machine }\end{array}$ & $\begin{array}{l}\text { Get used to } \\
\text { always checking } \\
\text { machine bith } \\
\text { before and after } \\
\text { the production } \\
\text { process is in } \\
\text { accordance with } \\
\text { Standard } \\
\text { Operating } \\
\text { Procedure } \\
\text { (SOP) }\end{array}$ \\
\hline
\end{tabular}

Control Stage:

Control stage is the last operasional stage in the CyclusDMAIC.Thissudy does not execise control, only limited to proposed improvements.

1. Deform 19 concrete iron production process which has the largest DPMO value in October with 12963 DPMO value and the conversion to sigma value of 3.727 and CTQ (critical to quality) with the highest defect is the type of line defect. So that in October the output of deform 19 concrete iron production has the lowest process capability compared to the other five months.

2. Based on the results of the CTQ root causes there are 3 factors that cause disability categories that affect the production process of deform 19 concrete iron are: humans in terms of fatigue doing work and not careful when checking the condition of the machine and the initial setting of the machine before the production process takes place; the engine in the event that the setting is not right so it experiences some damage such as bearing entry std. 11 and 15 jam / funny, roll guide std. 13 wear, entry std. 13 dies, std loop position. 15 pull, oil hose leaks, roll guide std. 15 wear; environment caused by the temperature of the work area (production room) heat.

3. Of the three factors that cause disability, a proposed improvement is needed to reduce the number of defects in deform concrete iron product 19 . Therefore, there is a need for more stringent supervision and control based on the tools for implementing kaizen $\mathrm{M}$ checklist and kaizen five step plan in things: give allowance to workers; provide training workers for refreshing standard operating procedures (SOP); accustom workers to work according to standard operating procedures (SPO); the application of strict punishment if the worker makes repeated mistakes; caring for the machine periodically so as not to be damaged or worn out quickly; cleaning the machine after the production process; get used to always checking machines both before and after the production process according to standard operating procedures (SOP); arrangement of air circulation equipment according to needs.

\section{CONCLUSION}

Based on research conducted at PT. Hanil Jaya Steel, the following conclusions can be drawn:

1. The quality level of deform 19 concrete iron products in July - December 2017 has a product defect of $3.22 \%$ and is at the sigma level of 3.9202 with DMPO of 8059.83 . DPMO and sigma values that deform 19 concrete iron products are included in the industry average in Indonesia.

2. To reduce defective production of deform 19 concrete iron products towards zero defects, the proposed improvement is based on kaizen implementation tools to improve product quality, namely: providing training workers for refreshing standard operating procedures (SOP); getting workers to work according to standard operating procedures (SOP); the application of strict punishment if the worker makes repeated mistakes; caring for the machine periodically so as not to be damaged or worn out quickly; cleaning the machine after the production process; 
get used to always checking machines both before and after the production process according to standard operating procedures (SOP); arrangement of air circulation equipment according to needs.

\section{REFERENCES}

[1] MBA: Six sigms vs Kaizen, Healthcare Administration program at Spring Arbor University.

[2] P.L. King, Kaizen Events as lean six sigma projects, Rapid improvement with structure and discipline, Lean Dynamics,LLc, May 2010

[3] Int. J. Quality \& Reliability Manag. Lean Six Sigma : yesterday, today and tomorrow Article information, vol 34 (4): pp 1073-1093, January 2017

[4] B.Haskin, Quality Control, Technical Informations Service, 2007.

[5] A.Medvedeva, International Conference on Six Sigma for Higher Education, 2017

[6] F.Manual, Journal Emeraldin Singht.com, 2013

[7] D.Amri H., The 4th International Conference on Technology and Operations Management, 2010

[8] S.H. Han, M.J. Chae, K.S. Im, H.D. Ryu, "Six sigma -based appoach to improve performance in Construction Operations," J. Manag. in Eng., January 2008

[9] P. Grima, L.M. Almagro, Six Sigma : Instructions from exercises to overcome difficulties," Sandrine Santiago \& Xavier Tort-Martorell, pp 198-208, August 2013

[10] Singh, Jagdeep, and H.Singh, "Continuous Improvement Approach : State of Art Review and Future Implications, Int. J. Lean Six Sigma, vol 3 (2), pp 88-111, 2012.

[11] A. Choudhury, Kaizen with Six Sigma Ensures Continuous Improvement, 2017

[12] D. Forgarty, Lean Six Sigma and Big Data, J. Manag. Innovation, vol 1(2), pp 1-6, 2015

[13] J.P. Atanas, Lean Six sigma Aplicationsin Oil and Gas Industry, Int. J. Scientific Res. Publ., vol 6 (5), May 2016

[14] A. Salloom, "The Impact of Applying the Total Quality Management and Kaizen Methods on the Maintenance of Electricity and Water sectors," Europe Scientific J., vol 12 (24), 2016

[15] D. Pavlovic, "The Ruole of Quality Method in Improving Education Process," Serbian J. Manag., vol 9 (2), pp 219-230, 2014

[16] R. Mahmod, F. Mashahadi, N.A. Ashari, "The Influence of Lean Six Sigma and Kaizen to Reduce Defect Product in Automative Industry, J. Emerging Econ. Islamic Res., vol 5 (4) , pp81-90, 2017

[17] H. Shang, A Literature Review on Kaizen, Yokohama J. Soc. Sci.,vol 22 pp 128, 2017

[18] S.H. Han, M.J. Chae, K.S. Im, H.D. Ryu, "Six sigma -based Appoach to Improve Performance in Construction Operations, J. Manag. in Engineering, January 2008 